Gregory Chin and Ramesh Thakur

\title{
Will China Change the Rules of Global Order?
}

Gregory Chin is an assistant professor of political science at York University in Canada and a senior fellow of the Centre for International Governance Innovation. He is the author of China's Automotive Modernization: The Party-State and Multinational Corporations (Palgrave Macmillan, 2010). He would like to thank the Social Sciences and Humanities Research Council of Canada and Alice Hu for research support. Ramesh Thakur is professor of political science at the University of Waterloo in Canada and adjunct professor of international relations at Griffith University in Australia. His most recent book, co-authored with Thomas G. Weiss, is Global Governance and the UN: An Unfinished Journey (Indiana University Press, 2010).

The multilateral order cannot hold if the power and influence embedded in international institutions is significantly misaligned with the real distribution of power. ${ }^{1}$ As power and influence seep out of the U.S.-led transatlantic order and migrate toward Asia and elsewhere, who will manage the transition from the Cold War system to its replacement, and how? ${ }^{2}$ Will it evolve or be overturned? Conversely, how successfully and quickly will rising powers respond to the challenge of changing from being free riders to stewards of the global order?

Since Beijing replaced Taipei to occupy China’s UN seat in 1971 and launched its economic reforms in 1978, the socialization of China into the behavioral norms of modern international society has been one of the defining stories of the last four decades. Beijing has demonstrated an impressive capacity to learn and adapt, albeit not without some difficulties. Analysts have focused mostly on the limits of the attractiveness of China's national models to

the global community, ${ }^{3}$ yet its international preferences and practices are not simply statist or 
mercantilist It is now set to embark on a qualitatively different phase of international engagement.

The rebalancing of power relations places China at a crossroads. One path, the predominant pattern to date, is China's continued socialization into global norms, rules, practices, and standards_as a "status quo" power_-helping mainly to maintain the post-1945 institutional arrangements. A second path would see a China that challenges more established global standards, rules, and norms of international conduct. If the established powers were to resist encroachments on their traditional privileges as the global norm setters and enforcers, this path could heighten tensions and even provoke conflict. In this article, we argue that China and the world will take a third way, of continued internalization by China of select global practices and norms, alongside registering its desire and right to be at the table for rewriting some others. We offer two main findings. First, Beijing has increased its engagement with global institutions, motivated largely by its growing integration and continuing reliance on some of the main institutions of global diplomacy, even while it has also sought to advance alternative institutional options such as the Shanghai Cooperation Organization or the China-ASEAN Free Trade As China and other rising powers reshape global agendas to better reflect their concerns, their sense of shared ownership in the governance institutions will continue to grow and encourage a greater sense of global obligation and increased stewardship. The challenge for the international community is to continue to encourage such a globalist transformation in China's behavior.

Second, in greater integration, China's approach reflects national interests as well as a desire to identify with other rising big powers such as Brazil and India. All three see themselves as developing countries still making the transition to major global players. They perceive their national interests as tied to exporting a variation of "the developmental state" as a new model.A 
more assertive China is encouraging a shift from a universal conception of political values to recognize diversity in human civilization, and recalibrating the multilateral order to set aside claims of universal civil and political rights to focus instead on solving common problems.

\section{Return to Historical Norms}

From 1000-1800 AD, Asia, Africa, and Latin America_today’s “developing world”accounted for 65-75 percent of global population and income. From 1870 to 1950, Asia’s per capita income plummeted from one-half to one-tenth of West European levels. ${ }^{4}$ But important changes have occurred over the past three decades as rapid industrialization and trade growth have given rise to the major emerging economies of Brazil, China, and India. The ascent of these countries has transformed the global financial system, with four of the world's five largest banks now Chinese.

For 20 years, China pursued a strategy of “coupling” its growth to the West, becoming an export powerhouse to satisfy the seemingly endless Western appetite for consumer goods. The strategy has dramatically raised living standards in China. But the global financial crisis has forced Beijing to pursue more domestic-driven growth, diversification to Southern markets, and gradual decoupling from U.S. and European markets. ${ }^{5}$ The contours of the emerging world economy are now being shaped by rising domestic consumption in China, the rise of Chinese multinational corporations, and the country's rise as an international creditor.

Beijing’s growing economic power and political influence have promoted a transformation in its foreign policy. For the past three decades, China has stuck closely to Deng Xiaoping’s cautious international strategy, to “conceal brilliance and cultivate internal strength” (tao guang yang hui), but things are starting to change. In a mid-2009 meeting between China’s 
most senior leaders and the country's top diplomats, a meeting which was largely ignored by the international media but reported in China’s official newspaper, Renmin Ribao (People’s Daily), President Hu Jintao told China's senior diplomats "to strive to make our country more influential politically, more competitive economically, and help ensure that our country has a more friendly image, with greater moral appeal.” He also told them that the global financial crisis was serving to reinforce multipolarization, That "peace and development remain the themes of our times, but that competition for overall national strength is becoming increasingly fierce. The demand of developing countries for equal participation in international affairs is becoming increasingly strong.” He emphasized that "we must defend our national development interests while also maintaining our openness to the outside world.”,

The speech was significant because it opens the way for a shift in China's foreign policy toward a more proactive global stance. It indicates that senior Chinese leaders recognize the need to rethink China's international strategy and go beyond Deng’s instruction. Even as some Chinese strategists argue that China should avoid international leadership and maintain a lower global profile, others suggest that it is unrealistic for China to continue to define itself as a "status quo" actor, given its growing global weight, and that it should play a more active role in global economic governance. ${ }^{7}$ Even those who argue that China is "ill prepared" to lead the world's needed adjustments because the country lacks experience in international financial systems management, at the same time acknowledge that China is "facing a turning point in its relationship with the international system. From passively accepting regulations of existing international financial institutions, the country will be joining the restructuring process for the first time.”8 


\section{A New Statist Model}

Although the United States is still the most influential international actor, the process of global economic, political, and moral rebalancing is in motion. The views of Brazil, China, and India on how to encourage stable and sustained national growth, while recalibrating the balance between citizens, states, and markets have gained traction of late. The Chinese see virtue in a strong state, a disciplined society, stable economic growth, and national security over "imported" notions of human rights, democracy, and unregulated markets.

In some enduring ways, China and India particularly share elements of post-colonial thinking, which reflect their specific historical experience. Memories in both countries of how their economies and societies were distorted in the past to serve the market and resource needs of colonial powers continue to shape their international strategic considerations. They have both faced a triple challenge of modern nation-building (national integration and forging a common national identity), state-building (the structures, institutions, and capacity of state), and economic development (poverty alleviation and economic modernization).

China’s continuing rise and the more recent successes of Brazil and India, combined with a global financial crisis that started in the U.S., have revived interest in a notion of a “developmental state,” with differing needs, strategies, and growth trajectories than the so-called “Anglo-American” model. The defining question for many countries watching today is which approach to balancing relations between citizens, society, market, state, the global economy, and which international normative order can produce the greatest gains in the performance for their own country? With the statist model, the goals of strengthening state capacity, promoting social cohesion, maintaining territorial integrity as well as political independence, resisting encroachments on national sovereignty, achieving economic growth to bankroll material 
progress and advancing the indicators of human development (e.g., gross domestic product per capita, maternal and infant mortality, life expectancy, literacy, etc.) receive top priority over human rights, democracy, and unregulated markets.

The shift in the balance of influence between the models has not only been driven by the developing world. Rather, a series of factors over the past decade, beginning with the tragic events of September 11, 2001, marked the beginning of a shift in the Western democracies themselves toward a heavier state hand. In the United States, the George W. Bush administration initiated a dramatic rise in internal state surveillance with the aim of protecting national security. This trend has morphed under the Obama administration into a greater regulatory role for the state over the national economy, and especially over the financial sector.

Although U.S. national security analysts have focused on the differences between the U.S. "free market" versus the "authoritarian capitalism" of China and Russia, ${ }^{9}$ what is remarkable about today is the increased overall acceptance of a greater role for state regulation of markets in the aftermath of the 2007-2009 global economic crisis. The political talk in Europe/Britain and the United States is about how to strengthen the regulatory framework for financial transactions in their respective sectors in order to avoid another massive taxpayer bailout. The fact that the current group of rising states went into the global crisis in a relatively strong and stable fiscal condition, and with large foreign currency reserves, coupled with their exit from the crisis earlier than others, has meant that states are paying closer attention to the policy ideas of the rising countries, both across the developing world and beyond.

Some analysts are suggesting that Beijing offers "a” China model, while others have tried to resurrect the idea of a "Beijing Consensus." ${ }^{10}$ Chinese scholars have largely refuted the idea of "a" China model, arguing that the country is too regionally and culturally diverse to have a single 
coherent model, with some locales facing pre-modern challenges, such as in the far reaches of Western China, and others dealing with post-modern problems in parts of Beijing, Hong Kong, and Shanghai. ${ }^{11}$ Moreover, one Chinese observer perceptively observes that other countries cannot really be said to be adopting a Chinese model unless they are also willing to "establish their own Communist Party or a similar political system." ${ }^{12}$ The implicit point is that such an outcome is highly unlikely in other parts of the contemporary world.

A close examination of China's actual development experience, with its unique path dependence, reveals that it would be exceedingly difficult for other countries to replicate. ${ }^{13}$ It is basically sui generis in that China's modernization success has been preconditioned by: 1) the country's size; 2) the mediating role and purposive coordination of the Chinese Party-state; 3) the specific policy trade-offs that were dictated by the backward situation of the Chinese economy at the start of the reform period in the late 1970s; and 4) the unique global conditions of expanding world markets and growth during the three-decade period from the early 1980s to the start of the twenty-first century.

These qualifications notwithstanding, China (along with Brazil and India) does offer potential development lessons from the last three decades for other states. All three countries are strong proponents of purposive state intervention to guide market development and national corporate growth, rather than relying on self-regulated market growth. They have promoted the norms of increased state intervention for market regulation, greater balance between the real economy and the virtual economy, and between the national market and international markets. The guiding logic behind state intervention is protecting, as much as possible, sovereign national development, or "economic sovereignty," even while seeking integration into the world economy. The primary lessons and norms that are being "exported" are to facilitate gradual and 
managed integration into global trade and financial markets, and to maintain national-state controls in a globalized economy where financial and economic crises are recurrent but unpredictable while collective insurance from major global multilateral institutions to manage crises cannot be relied upon. The emphasis on ensuring national developmental steering capacity and capital controls, even while pursuing increased economic integration, marks China (and Brazil and India) from the previous group of newly industrializing countries of the late 1980s to mid-1990s in Southeast Asia.

China’s greater reliance on joint ventures between multinational corporations and Chinese partners, and larger inflows of foreign investment also differentiate the Chinese state-led developmental experience from that of the other Northeast Asian cases of Japan, South Korea, and Taiwan. The other cases reduced their reliance on foreign investors after their initial stage of catch-up modernization was safely underway. The current rising states have each put greater attention into utilizing and directing foreign investors inside their national contexts, building up the bargaining power of the host state with foreign multinationals, and promoting the development of their own globally-competitive companies. ${ }^{14}$ China and the other current risers have also practiced a strategy of accumulating large-scale foreign currency reserves, both to insulate their nations from externally-induced financial and currency shocks, and to provide a ready stock of foreign currency to their national development banks to pursue national developmental goals.

This general developmental model of governance is not just one that other countries might emulate, but one that Beijing is starting to promote internationally, including through its foreign assistance to Southern states. In the policy advice accompanying its foreign assistance to Africa and Latin America, for example, Beijing has emphasized the importance of state 
intervention to ensure that national resources can be used to leverage investment and loans from the wealthier parts of the world. ${ }^{15}$ Chinese authorities have stressed identifying core or pillar industries, as well as providing appropriate state support to, and regulation of, these sectors. They have emphasized the importance of foreign exchange reserve management and payments balances. The Chinese central bank and finance ministry, and other economic ministries, have worked with their counterparts in African states, and officials of the African Development Bank to share China’s lessons on fiscal management, and the financing of planned national development projects, including preferred balances between the financial sector, infrastructure, industrial and agricultural development. ${ }^{16}$

To take one specific example, in Western economic thought, banks are seen as intermediaries between borrowers and lenders. Traditionally in Asia, however, banks are seen as instruments of state-directed growth and industrialization which take deposits and then use the savings through preferential allocation of credit to drive development in predetermined priority sectors of the economy. ${ }^{17}$ China's People’s Bank, Ministry of Finance, and major policy banks, such as the China Development Bank and the State Export-Import Bank, have worked with their southern counterparts on how to become "responsible borrowers," and how to identify and structure revenue and surplus-generating projects so that a stable supply of funds is available to repay loans. ${ }^{18}$ Chinese experiences on public financial and fiscal management are a core component in the curriculum of this government-to-government training.

In macroeconomic terms, the spread of the economic nationalist model of the rising states could lead to lower overall global growth. However, China and the other risers appear to be willing to accept the trade-off of somewhat lower growth for increased macroeconomic stability 
and sustained growth, instead of potentially higher but volatile "free market" boom and bust cycles.

\section{Managing the World Economy}

The roots of this shift, and the transition toward the national statist model, can be traced back over a decade to the Asian financial crisis of 1997-1998. Asians were deeply displeased with the IMF's crisis management, which followed the rules of the so-called Washington consensus advocating free market fundamentalism. Instead, after the 1997-98 crisis, Asian countries sought the accumulation of large currency reserves and the domestication of debt to insulate themselves from financial systemic shocks. Asia has continued to focus on pursuing growth and development through domestic savings and capital accumulation, increased private and official aid flows, and improved market access for its goods.

For most of the three decades prior to the 2007-2009 global financial crisis, China had become increasingly reliant on the advanced markets of Europe and the United States to facilitate export-led growth. During this period, China largely took to "learning” the rules of global order. ${ }^{19}$ The high point of its socialization to global practices and norms was in the terms of China's 2001 accession to the World Trade Organization (WTO), when it accepted an unprecedented list of international commitments to gain entry into the global trading regime. ${ }^{20}$ Beijing went farther than most international experts had predicted in implementing the comprehensive transparency obligations of the WTO. ${ }^{21}$

But since the late 1990s, after the Asian financial crisis and as China's economy began its dramatic climb, Beijing started to invest a growing amount of diplomatic resources into building alternative institutional options to the Bretton Woods rules, such as strengthening regional 
development banks across the Global South, establishing new multilateral trade arrangements such as the China-ASEAN Free Trade Area (CAFTA, and together with the Asian Development Bank, the Central Asia Regional Economic Cooperation (CAREC) forum. ${ }^{22}$ These and other potential routing-around options caught the attention of foreign observers in 2006, when Beijing hosted over 50 African leaders at the Fourth Forum for China-Africa Cooperation (FOCAC). China announced that it would provide Africa with over $\$ 10$ billion in preferential credits and direct investment, double grant assistance to help build hospitals as well as malaria prevention and treatment centers, assist in constructing schools in rural areas, help to build a conference center for the African Union, and cancel all interest-free loans owed by eligible countries that had matured by the end of $2005 .{ }^{23}$ The large foreign aid agreement, combined with the new China-Africa Strategic Partnership Agreement that was signed during the Beijing FOCAC Summit, dramatically overshadowed the actual results from the G7/8's “historic” African Outreach announcements at Gleneagles, Britain in 2005, when the grouping promised \$50 billion in new aid to Africa, and to cancel the outstanding debt of the highly indebted poor countries. Many G7 countries did not follow through on the additional aid commitments to Africa, and close investigation revealed that portions of the 'newly promised' aid funds were actually repackaged funds that were already pledged. ${ }^{24}$ In contrast, China's growing trade and purchases of commodities from resource-rich African countries gives those countries more money with which to buy manufactured goods, in which China enjoys a global comparative advantage. The newly-created China African Development Fund alone is targeted to make $\$ 5$ billion available for Chinese investment in Africa, whereas the total amount of Chinese investment in Africa for 2000-2006 had totaled \$6 billion, according to China’s commerce ministry. 
In its growing international relations to date, China has reaffirmed Westphalian norms of state sovereignty and responsible international behavior such as nonaggression, nonintervention, and noninterference in internal affairs. The global financial crisis has, however, brought important changes in China's international behavior. Beijing has given new emphasis to reengaging the Bretton Woods institutions. Amidst the crisis, low-income countries learned that the new powers were not yet able or willing to supplant these existing global institutions and take on global crisis management responsibilities, especially global lender-of-last-resort functions. The crisis showed that the vulnerable low-income countries would, at some level, still have to return to the Bretton Woods institutions to deal with the fast-spreading crisis. The rising states did, however, provide support by pushing for more responsive, flexible, and rapid financing to the low-income countries, to help them ward off the contagion effects of the crisis and shore up their national developmental objectives. Through the G-20, China helped push for a paradigm shift toward countercyclical policy in emergency lending. ${ }^{25}$ In this respect, Beijing has exhibited a preference to date for strengthening the traditional Westphalian conception of sovereign national economic development within the existing Bretton Woods system, rather than replacing it.

However, during the crisis, the rising states also called for reforming the international monetary system. At various points throughout 2009, they called on the international community to consider diversifying beyond the dollar as the de facto global currency, and to take gradual steps in expanding the role of the IMF's Special Drawing Rights as a supplemental global reserve asset option. China's central bank governor, Zhou Xiaochuan, suggested that the world needs an international currency option "that is disconnected from individual nations and is able to remain stable in the long run, thus removing the inherent deficiencies caused by using credit- 
based national currencies. ${ }^{26}$ In advocating for expanding this supranational option, Beijing is also promoting an agenda of diversifying beyond the existing currency order, which the U.S. would surely resist as long as it has the capacity to do so. The current scenario is therefore ambiguous, where China’s central bank and finance officials are demonstrating 'learning’ of established multilateral practices, norms, and rules, as well as efforts to reshape the de facto dollar-based monetary system. They are able to do so, based on their accumulated knowledge of the system's shortcomings, drawn from their intimate engagement within the institutions over the past three decades.

\section{Leveraging UN Security Council Permanent Membership}

The institutional channel where China's international learning — and consequent Reshaping — of global rules and standards can best be seen is in the UN system. The UN has arguably been the most active global multilateral organization to respond strategically to China's rise, and to leverage China's growing weight among the rising powers for multilateral cooperation. For example, the UN worked with Chinese and African authorities to establish the China-African Business Partnership and the China-Africa Business Council, both of which started in 2005. The UN Development Programme (UNDP) also led a multi-donor effort to help establish the International Poverty Reduction Center in Beijing in 2006, whose mission is to transfer the best practices and lessons of China's own development experience to other developing countries. ${ }^{27}$ China has been a key donor to the UNDP's Voluntary Trust Fund for the Promotion of South-South Cooperation. Through these UN channels, China has encouraged “ongoing development dialogue between countries in the Global South.,28 
China's relations with the UN has evolved even further in recent years as a result of its growing capabilities and willingness to contribute to UN-led humanitarian and developmental efforts and peace operations, for example in Haiti. China’s nearly 130 police officers was the largest group among the UN contingent. China first deployed these troops in September 2004, to help quell unrest that had broken out after severe flooding; to help maintain law and order, and rebuild the judicial system. ${ }^{29}$ China’s role in UN peacekeeping operations has expanded dramatically over the last decade, and Beijing has provided more peacekeepers than any other permanent member of the Security Council. ${ }^{30}$ Beijing currently is the 14th largest troop contributor to UN peacekeeping with nearly 2,140 soldiers and police in $10 \mathrm{UN}$ missions, including Sudan, Haiti, Liberia, and Lebanon. The UN peacekeeping force commander in Western Sahara is a Chinese national.

The UN itself has proven unusually adept over the last decade at encouraging Beijing to adopt global norms and best practices, as seen in revisions to the Chinese legal system in the areas of disability, environmental sustainability, and anti-corruption. ${ }^{31}$ This can be seen in amendments to Chinese laws and rules to establish the rights of the physically disadvantaged; new environmental protection norms, rules and rights; and China's adoption of global norms for building accountable, transparent and ethical government. The changes to Chinese laws draw directly from the related UN conventions on the disabled, on climate change, and against corruption.. Even in areas of law where the gains have been partial, such as China's adaptation to the UN Conventional on Civil and Political Rights, there has been some progressive, partial convergence with the UN's international norms, for example, in the drastic reduction of the number of crimes for which the death penalty will be applied, from sixty eight offenses previously to less than twenty. ${ }^{32}$ Chinese officials and legal scholars note that the elimination of 
execution for non-violent crimes is a move that is meant to bring China into closer conformity with international (read: Western) legal norms, and they name the UN Convention Against Corruption, and the Convention on Civil and Political Rights specifically. ${ }^{33}$

Another illustration of Chinese learning of new global norms is the speed with which Beijing adapted earlier this decade to the rise of the responsibility to protect—or R2P as it is now commonly called — that was formulated by the International Commission on Intervention and State Sovereignty (ICISS). ${ }^{34}$ Initially, during the ICISS outreach process in $2001,{ }^{35}$ the Chinese argued that humanitarianism is good, interventionism is bad, and humanitarian intervention is tantamount to marrying good to evil. China argued that there was no basis for humanitarian intervention in the UN Charter, which recognizes only self-defense and the maintenance of international peace and security as legitimate grounds for the use of force. Its use for moral reasons, they argued, is dangerous and counterproductive. On one hand, it can encourage warring parties inside a country to be rigid and irresponsible in the hope of internationalizing the conflict. On the other hand, it can facilitate interventions by outsiders exploiting the cloak of legality for their own purposes. Far from ending or ameliorating the effects of large-scale killings, both sets of unintended effects can prolong and aggravate crises.

And yet, in 2005, China's official paper on UN reforms surprisingly accepted the need for R2P: "Each state shoulders the primary responsibility to protect its own populatio. When a massive humanitarian crisis occurs, it is the legitimate concern of the international community to ease and defuse the crisis.” ${ }^{36}$ But Beijing remains insistent on keeping the scope of R2P to the four narrow categories specified in the 2005 World Summit's outcome document-war crimes, crimes against humanity, genocide, and ethnic cleansing — and requires Security Council authorization as a necessary precondition for any international action. In a Security Council 
debate on December 4, 2006, Ambassador Liu Zhenmin warned that the Outcome Document was “a very cautious representation of the responsibility to protect populations from genocide, war crimes, ethnic cleansing and crimes against humanity... it is not appropriate to expand, willfully to interpret or even abuse this concept." 37 This interpretation is one way that China is shaping global norms and rules, interpreting Western Enlightenment principles through a Confucian lens of governance which stresses an essential unity between citizens and state, rather than giving primacy to human rights as claims against the state.

China is also using its enhanced UN engagement to expand its influence in reshaping other international practices. For example, over the past decade, Beijing has been providing growing amounts of bilateral foreign assistance (estimated at \$35-50 billion per annum by 2008 to an expanding list of developing countries around the world. ${ }^{38}$ But China’s approach to providing aid challenges the practices of traditional donors both on content and implementation. Infrastructure is central to the content of China's aid programs. Compared to traditional donors, including the World Bank, Chinese infrastructure projects tend to be finished in a shorter time and at lower cost. The effectiveness of China's aid can cut into the relative influence of the Bank and the Fund.

In terms of implementation, the West has promised local ownership and capacity building, but its support has come with conditionality, such as the need to adjust economic policies and redirect state expenditure to ways deemed appropriate by the traditional donors or the major multilateral lenders. ${ }^{39}$ China is much less demanding on conditionalities, except on the acknowledgement of “one China.” Traditional multilateral coordination forums, such as the Development Assistance Committee of the OECD (Organization for Economic Cooperation and Development) and the Consultative Group of donors led by the World Bank, have sought to 
coordinate or harmonize Chinese efforts with existing practices and reinforce aid conditionality. Yet it is not surprising that, although Beijing has been willing to explore some possibilities for cooperation, ${ }^{40}$ overall it has been reluctant to coordinate or harmonize its aid programming with the traditional donors. Chinese authorities see little to be gained by associating themselves too closely with traditional donors when the latter have been seen by many borrowing countries as an aid cartel, largely imposing their own preferences on recipients.

\section{The Bilateral Fulcrum for Global Order}

For the first time in 200 years, the world has to cope with a unified and powerful China as it seeks to use its revitalized national power to shape global institutions and practices to its preferences. But China also has to come to terms with its new global status. Although China's relations with its Asian neighbors will continue to evolve, the pivot for redefining China's global policy, and the implications for world order as China reemerges on the global stage, will be Beijing's relationship with Washington.

Undoubtedly, there are serious differences of interests between Beijing and Washington. China has made the most of U.S. entanglement in Afghanistan as well as Iraq and the crises of U.S. moral and financial prestige to expand Chinese soft power. China’s rise has been welcomed by some countries as a counterweight to U.S. military muscle and political arrogance, and many look to it as the world's new engine of growth. As a result, a de facto G-2 has emerged in some

observers' minds. ${ }^{41}$ Although neither government wants to give the relationship such a grandiose title, both are investing significant resources in bilateral diplomacy, capped off by the U.S.-China Strategic and Economic Dialogue (S\&ED). 
China may be the new global production capital, but the United States remains the financial, monetary, and consumption capital of the world. The United States needs China to help finance its mountainous debt—projected to hit $\$ 9$ trillion over the next decade— however the United States simultaneously remains vital to China’s economic health and future well-being. A collapse of the U.S. economy would mean drastic cutbacks in the export of Chinese-made products and depreciation of Beijing’s \$2.4 trillion reserves. The U.S.-China economic imbalances have created interdependence, and the obstacles to reversing the imbalances are immense. Dealing with their differences on the dollar-RMB exchange rate is only the beginning. Both sides have pledged that they will change their behavior — China by consuming more and exporting less, and the United States the reverse-in order to bring about the desired rebalancing. Despite the change in behavior, imbalances are likely to persist, and will be a recurrent drag on relations.

It is, nonetheless, vitally important for China to get this key bilateral relationship "right" if its continuing rise is to be secured. Beijing ought to be worried that the 2010 U.S. Quadrennial Defense Review expressed concerns over the lack of transparency in China's military development and decisionmaking processes. ${ }^{42}$ China should respond appropriately to these concerns, especially as the same report welcomed India's rising global profile "as a net provider of security in the Indian Ocean and beyond." ${ }^{43}$ Beijing, in turn, is concerned about the potential long-term presence of U.S. forces based in Afghanistan and Central Asia. These considerations help to explain the strategic basis of China's relationship with Iran, the only autonomous oil producer in the Middle East. A nuclear but independent Iran may be in China's strategic interest compared to a nonnuclear Iran under U.S. domination, which may help explain China’s “delayand-weaken” tactics on UN sanctions on Iran. ${ }^{44}$ But at the heart of the matter, along with most of 
Asia, China does not believe that sanctions are an efficacious policy tool. They are a blunt instrument that rarely works to achieve the stated objectives. ${ }^{45}$

Beijing has, however, moved recently on the Iran issue. At a meeting on the margins of the Washington Nuclear Summit hosted by President Barack Obama in April 2010, President $\mathrm{Hu}$ agreed that Chinese officials would work with the U.S. delegation on a UN sanctions resolution. This culminated in Security Council Resolution 1929 in June 2010 that imposed new restrictions on trade with Iran. Jeffrey Bader, senior director for Asian affairs at the National Security Council, said that the agreement between the two countries' top leaders was "a strong indication of the way in which the U.S. and China are working together in a positive way on Iran and other issues. ${ }^{46}$

Equally important for U.S.-China security relations, China has been a key partner on the Six-Party Talks on the Korean Peninsula to help manage relations with North Korea and its threats of nuclear escalation. Also in the key East Asian theater, a reasonable and negotiated solution between China and the United States can even be achieved on the Taiwan issueassuming there are no changes in the "one China” policy. When Washington announced \$6 billion arms sales to Taiwan—including missiles, helicopters, and mine-hunting ships—Beijing retaliated by suspending bilateral military exchanges and imposing sanctions on companies selling arms to Taiwan. But at a deeper level of strategic calculation, and beyond the diplomatic bluster, Beijing can comprehend and anticipate the Congressional politics that helps drive decisions to proceed with arms sales, and what the administration can and cannot give regarding Taiwan. For example, the leading US-China research team at the Chinese Academy of Social Sciences has shown such balanced and measured judgment in writing of the need for China-US relations to move toward "maturity." ${ }^{47}$ During the recent period of worsening US-China tensions 
(late 2009-early 2010), another influential ‘America strategist' for China, Yuan Peng of the China Institute of Contemporary International Relations has emphasized that "bilateral relations between China and the U.S. involves many global issues... The fight against...regional and global security issues all require cooperation between China and the U.S.. The two sides should face up to the differences between them and develop a long term strategy in dealing with global challenges." ${ }^{48}$ Unpredictability and geostrategic uncertainty are of much greater concern for Chinese or any other country's foreign policy strategists.

What China and the United States do, either alone, together, or with their respective allies in global multilateral and regional forums, will increasingly define the "limits of the possible" for global governance. Amid the global economic crisis, both China and the United States showed that they are interested in working together and, equally important, in embedding their bilateral relations in multilateralism. The G-20 Leaders process, which began in late 2008 at the Washington DC Summit has emerged as their preferred platform, at least for financial crisis management and possibly for directing the Bretton Woods institutions more broadly. How the United States and its closest allies inside the G-20 respond to China’s growing presence will have a significant bearing on whether China will seek to be integrationist or focus more instead on turning its supplemental regional institutions, such as the 'Chiang Mai Initiative multilateralized' or a strengthened Asian Development Bank into options that advance an alternative set of practices, norms, rules, and standards.

Recently, a group of states within the G-20 (Canada, France, South Korea, the United Kingdom, and the United States), frustrated by the lack of progress in overcoming the political gridlock on global financial and trade [Greg] imbalances, and particularly what they understand as a problem of misaligned exchange rates, have started to go public with their frustration. In the 
lead up to the June 2010 G-8/G-20 Summits in Toronto, they issued a joint letter "reminding” the 20 of the rebalancing obligations agreed to at the G-20 in Pittsburgh in September 2009. ${ }^{49}$ More troubling to Beijing is that Brazil and India—-key diplomatic partners for China in the G-20— may be shifting to join the chorus of criticism on the RMB exchange rate. These diplomatic developments could be the result of an evolution in U.S. strategy, to work more closely with other major developing countries rather than just its G-7 allies, in leveling criticism at Beijing. Just as China can hedge its international engagements, so the West and other major emerging countries can hedge in engaging China.

Nonetheless, conciliatory gestures may not come from China in response to multilateral pressure on exchange rates and imbalances. Beijing made sure to announce prior to the G20 Toronto Summit in June 2010 that it had decided to de-peg the Chinese currency from the dollar, and emphasized that the management of the value of the renminbi is a matter of national policy, and that other states should respect policy sovereignty. What may furthermore be troubling for the West is that recent data, including from ANZ Bank, suggests that Asia has started to economically “decouple” from the West by generating more internal demand for its own products. ${ }^{50}$ Coming out of the crisis, China's economic heft has expanded further, in both its share of imports and retail sales. Equally significant for the global system, the Chinese gains were greater than losses in U.S. imports and retail sales. These new economic patterns provide a basis upon which Beijing can promote alternative international cooperation options if the West comes to the G-20 or Bretton Woods table only with pressure tactics.

\section{Realizing Interests [CT: ok?] [OK]}


The interests of the West lie in encouraging Beijing to act as a system reformer, working toward constructive and necessary changes within existing Bretton Woods and the other established institutional arrangements. In a context of global financial freefall, the same could be said of the interests of China’s Asian neighbors and even the other emerging powers.

To the extent that China actually wants to seek both reform and accommodation as it integrates further into the system, Beijing will have to work out and effectively convey the tangible contributions and sacrifices it is prepared to make for the greater global good, even as it also promotes reforms. There are some hopeful signs of late. While some China watchers have emphasized the tough tone emanating from China since the financial crisis, related to the SinoUS tensions, the Copenhagen climate change conference, Internet freedom, and China's border with India ${ }^{51}$, the reality is that Beijing has begun to backtrack on a number of these fronts to seek a more conciliatory posture. Some senior officials who took a "tough" diplomatic line in dealing with the United States have been shuffled out of their previous positions of representation. For example, He Yafei, the lead negotiator at Copenhagen and the G-20, was reassigned as ambassador to the United Nations in Geneva in January $2010 .^{52}$

Despite the significant domestic development challenges that China still faces, its growing global profile means that Beijing will need to demonstrate that it understands and accepts the increased global obligations that come with its new status as a great power. One major source of new friction may be Western firms that feel frozen out of the Chinese market or undercut by heavily subsidized state-owned enterprises. Another is countries feeling that China is taking a more assertive approach to regional disputes and waterways such as the South China Sea or foot-dragging on global security concerns. It is equally vital for the West to understand that Beijing will not be willing to simply accept more responsibility without gaining some of the 
benefits of leadership. To date, Washington has been more willing to talk about burden sharing and less forthcoming about power sharing.

Without such a balanced discussion between shared global leadership and burden sharing, it is likely that China will either 'foot-drag' or look to circumvent global discussions that are driven by the traditional powers. China, however, should be mindful that, just as it can hedge, so can the West and its likely Asian partners such as India and Japan. A reversion to an oldfashioned "balance-of-power" scenario would be unfortunate for all, especially if absent effective coordination mechanisms between the paramount powers. 


\section{Notes}

1 See Edward Newman, Ramesh Thakur, and John Tirman, eds., Multilateralism under Challenge? Power, International Order, and Structural Change (Tokyo: UN University Press, 2006).

2 See Se Sung Won Kim, David P. Fidler, and Sumit Ganguly, “Eastphalia Rising? Asian Influence and the Fate of Human Security,” World Policy Journal 26, no.2 (Summer 2009): 53-64.

3 See Lai-Ha Chan and Gerald Chan, “Rethinking Global Governance: A China Model in the Making?” Contemporary Politics 14, no. 1 (March 2008): 3-19; Barry Naughton, “China’s Distinctive System: Can It be a Model for Others?” Journal of Contemporary China 19, no. 65 (2010): 437-460.

$4 \quad$ See Deepak Nayyar, Developing Countries in the World Economy: The Future in the Past? (Helsinki: UN University World Institute for Development Economics Research, WIDER Annual Lecture 12, 2009), p. 41.[

$5 \quad$ Wang Yong, “Domestic Demand and Continuing Reform: China’s Search for a New Model,” Global Asia, 3, no.4 (Winter 2008), pp. 23-28.

6 Wu Qimin, “Notes: China Held a Top Diplomatic Envoys Meeting, President Hu Emphasized Promoting Economic and Political Power and Building Moral Image,” People’s Daily, , July 20, 2009 (in Chinese).. We thank Chris Buckly for bringing this speech to our attention.

7 See Pang Zhongying, “Zhongguo zai guoji tixi zhong de diwei yu zuoyong” [China’s status and role in the international system], Xiandai guoji guanxi [Modern international relations], no.4 (2006): 17-22 and the views of Huang Ping are cited in You Nuo, Fu Jing, and Wang Bo, “China Should Play Greater Role in G-20 , Expert Says,” China Daily, March 19, 2009, http://www.chinadaily.com.cn/bizchina/2009-03/19/content_7594063.htm.

$8 \quad$ Wang Zaibang, “International Situation 2008: Historic Transformations Highlight Urgent Need for Systemic Readjustments,” Contemporary International Relations (Beijing), 19, no.2, pp. 65, 66.

“National Security Strategy,” May 2010,

http://www.whitehouse.gov/sites/default/files/rss_viewer/national_security_strategy.pdf.

10 Stefan Halper, The Beijing Consensus: How China's Authoritarian Model Will Dominate the Twenty-first Century (New York: Basic Books, 2010). The term “Beijing Consensus” first came to prominence in Joshua Ramo Cooper, “Beijing Consensus,” May 2004, http://fpc.org.uk/fsblob/244.pdf. Also, for a Chinese perspective, see Zhongying Pang, “China’s Soft Power Dilemma: The Beijing Consensus Revisited,” in Mingjiang Li, ed., Soft Power: China's Emerging Strategy in International Politics (Lanham, MD: Lexington Books, 2009), pp. $125-142$. 11 Remarks by one of China’s leading sociologists, Dr Huang Ping. Presentation at a conference on “Beijing Consensus, China Model or What?” that was organized by the Chinese Academy of Social Sciences, Institute for 
Comparative Politics and Economics of the Central Translation, Official Documents Bureau of the CCP, and Tianjin Normal University in Tianjin, September 2005.

12 Quoted in Yoichi Funabashi, “Interview with Wang Jisi: For China, Stability Inside—and Outside—Key for Future Prosperity,” Asahi Shinbum, June12, 2010.

13 For a detailed discussion see Gregory Chin, China's Automotive Modernization: The Party-State and Multinational Corporations (Basingtoke: Palgrave Macmillan, 2010). , especially pp.22-47, 230-231.

14 A current hot political controversy in India concerns the huge disparity in accountability to the host government and peoples between British Petroleum for the oil spill in the Gulf of Mexico in 2010, in which 11 people were killed, and Union Carbide for the Bhopal gas tragedy in 1984, in which 15,000 people were killed.

15 See Deborah Brautigam, The Dragon's Gift: The Real Story of China in Africa (Oxford: Oxford University Press, 2009), pp.145-148..

16 Such transfer of Chinese public financial lessons reached public attention at the annual meeting of the African Development Bank in Shanghai on May 16-17, 2007, which was hosted by the Chinese government, and chaired by Chinese central bank governor Zhou Xiaochuan. See: “China Prepares for Upcoming ADB Meeting in Shanghai”, People's Daily (English edition), May 14, 2007. <http://english.people.com.cn/200705/14/eng20070514_374232.html>

17 John Whalley, et al., China and the Financial Crisis (Waterloo, Ontario: Centre for International Governance Innovation, Report of the CIGI/Chinese Academy of Social Sciences Task Force, 2010), p. 11. http://www.cigionline.org/sites/default/files/Task_Force_2.pdf.

18 Discussions with leading representatives of the State Export-Import Bank of China, Beijing, February 2007.

19 See Margaret M. Pearson, “The Major Multilateral Economic Institutions Engage China,” in A.I. Johnston and Robert S. Ross, eds., Engaging China: The Management of an Emerging Power (New York: Routledge, 1999), pp. 207-234 and Alastair Iain Johnston, “Is China a Status Quo Power?” International Security 27, no. 4 (Spring 2003): 5-56.

20 Nicholas Lardy, Integrating China into the World Economy (Washington, DC: Brookings Institution Press, 2002).

$21 \quad$ For examples of the pessimistic initial predictions see: Sylvia Ostry, "China and the WTO: The Transparency Issue,” UCLA Journal of International Law and Foreign Affairs, 3, no.1, Spring/Summer 1998, pp.122; Pitman Potter, "China and the International Legal System: Challenges of Participation," China Quarterly, 191, 1997, pp.699-715. For how China has implemented many of its WTO accession obligations and operating within WTO rules see: Margaret Pearson, "China in Geneva: Lessons from China’s Early Years in the World Trade Organization,” in Alastair Iain Johnston and Robert Ross (eds.), New Directions in the Study of China's Foreign 
Policy (Stanford: Stanford University Press, 2006), pp.242-275; Scott Kennedy, “China’s Porous Protectionism: The Changing Political Economy of Trade Policy,” Political Science Quarterly, 120, no.3, 2005, pp.407-432.

22 For the example of CAFTA see: Gregory Chin and Richard Stubbs, "China, Regional Institution-Building and the China-ASEAN Free Trade Area ," (forthcoming in Review of International Political Economy, 2011).

23 Source: "Full Text: Address by Hu Jintao at the Opening Ceremony of the Beijing Summit of the Forum on China-Africa Cooperation”, FOCAC Summit website (Chinaview.cn), November 4, 2006,

$<$ http://english.focacsummit.org/2006-11/04/content_4978.htm>

24 International monitors have found that large amounts of the additional G7 aid was often used to facilitate the privatization of public services to businesses from the donor countries.

$25 \quad$ See Gregory Chin, "Remaking the Architecture: The Emerging Powers, Self-Insuring and Regional Insulation,” International Affairs 86, no. 3 (May 2010): 693-715.

26 Zhou Xiaochuan, “Reform the International Monetary System” (speech, [CT: please provide location and date of speech]), http://www.pbc.gov.cn/english/detail.asp?col=6500\&id=178.

27 “From across the globe - Khalid Malik on China's unprecedented capacities to tackle poverty, development partnerships and the financial crisis,” UNDP: Capacity Building in Europe and CIS (official website), April 14, 2009, http://europeandcis.undp.org/cd/show/5428589E-F203-1EE9-BB06D9BC5D5E2F56.

28 See UN Development Programme, “Forging a Global South,” December 19, 2004, http://www.undp.org.cn/downloads/ssc/forgingaglobalsouth.pdf

29 “China Police to Keep Haiti Peace”, BBC News, September 29, 2004 <http://news.bbc.co.uk/2/hi/asiapacific/3701142.stm>

30 Colum Lynch, “In Surprise Move, China Withdraws Riot Police from Haiti”, Foreign Policy, March 25, 2010

<http://turtlebay.foreignpolicy.com/posts/2010/03/25/in_surprise_move_china_withdraws_riot_police_from_haiti>

$31 \quad$ We thank Khalid Malik for highlighting these examples.

32 Cao Li, “China Mulls to Cut Down Executions”, China Daily, July 24, $2010<$ http://www.chinadaily.com.cn/china/2010-07/24/content_11044407.htm>

33 Gregory Chin, as a Canadian government official, conducted extensive research from June-November 2006 on China's adaptation to the UN Conventions on Civil and Political Rights, Against Corruption, and Social and Economic Rights, , including numerous interviews with Chinese and international legal scholars, and Chinese officials in the relevant state institutions.

$34 \quad$ See Ramesh Thakur and Thomas G. Weiss, “R2P: From Idea to Norm—and Action?” Global

Responsibility to Protect 1, no. 1 (January-March 2009): 22-53.

35 Ramesh Thakur was an ICISS Commissioner and the 2001 comments are drawn from his own notes. See

Ramesh Thakur, The Responsibility to Protect: Norms, Laws and the Use of Force in International Politics

(London: Routledge, forthcoming). 
36 “Full text of China's position paper on UN reforms,” Xinua News Agency, June 7, 2005, http://news.xinhuanet.com/english/2005-06/08/content_3056817_3.htm.

$37 \quad$ Quoted in Sarah Teitt, “Assessing Polemics, Principles and Practices: China and the Responsibility to Protect,” Global Responsibility to Protect 1, no. 2 (April 2009): 216.

$38 \quad$ China started providing foreign assistance to Africa in the late 1950s, and to Latin America in the 1960s. 39 See Deborah Brautigam, The Dragon's Gift: The Real Story of China in Africa (Oxford: Oxford University Press, 2009), pp. 132-135.

$40 \quad$ See Gregory Chin, “China’s Rising Institutional Influence,” in Alan S. Alexandroff and Andrew F. Cooper, Rising States, Rising Institutions: Challenges for Global Governance (Washington, D.C.: Brookings Institution Press, 2010), pp. 83-104.

41 Geoffrey Garrett, "G-2 in G-20 : China, the United States and the World after the Global Financial Crisis,” Global Policy 1, no. 1 (January 2010): 29.

42 “Quadrennial Defense Review Report,” February 2010, p. 60, http://www.defense.gov/qdr/images/QDR_as_of_12Feb10_1000.pdf.

$43 \quad$ Ibid.

$44 \quad$ International Crisis Group, “The Iran Nuclear Issue: The View from Beijing,” Asia Briefing, no. 100 , February 17, 2010.

45 See Ramesh Thakur, "Sanctions: A Triumph of Hope Eternal over Experience Unlimited,” Global Dialogue 2(3), Summer 2000, pp. 129-41.

$46 \quad$ Merle David Kellerhals Jr., "U.S., China Share Concern Over Iranian Nuclear Program”, U.S. Department of State website, April 13, 2010. < http://www.america.gov/st/peacesecenglish/2010/April/20100413123029dmslahrellek0.7025873.html>

47 See Huang Ping, Tao Wenzhao, Wang Rongjun, Yuan Zheng, and Zhao Xingshu, “China-US Relations, Tending Towards Maturity” (English translation), The International Spectator, 44, no.2, June 2009, pp.9-16. <http://ias.cass.cn/en/show_project_ls.asp?id=1012>

$48 \quad$ Yuan Peng's views are cited in Mo Hong'e, “China, US to Build Cooperative Relations”, China Daily, May 26, 2010 < http://news.xinhuanet.com/english2010/video/2010-05/26/c_13316112.htm>

49 Chris Giles and Alan Beattie, “China Reprimanded by G-20 Leaders,” Financial Times, March 30, 2010.

$50 \quad$ Alan Wheatley, “An Appetite that Changes the World,” International Herald Tribune, April 27, 2010, p.

22.

$51 \quad$ See John Pomfret, “China’s Strident Tone Raises Concerns Among Western Governments, Analysts,”

Washington Post, January 31, 2010, http://www.washingtonpost.com/wp- 
dyn/content/article/2010/01/30/AR2010013002443.html; Geoff Dyer, “The Dragon Stirs,” Financial Times,

September 25, 2009; David Shambaugh, “The Year China Showed Its Claws,” Financial Times, February 17, 2010.

52 Neil MacFarquhar, “6 Major Powers Move Closer to Considering More Iran Sanctions”, New York Times, January 16, 2010. <http://www.nytimes.com/2010/01/17/world/middleeast/17nations.html> 